\title{
PHOTOSYSTEM II FLUORESCENCE AND GROWTH IN CABBAGE PLANTS (Brassica oleracea var. capitata) GROWN UNDER WATERLOGGING STRESS
}

\section{FLUORESCENCIA DEL FOTOSISTEMA II Y CRECIMIENTO EN PLANTAS DE REPOLLO (Brassica oleracea var. capitata) EXPUESTAS A ESTRÉS POR ENCHARCAMIENTO}

\author{
Fánor Casierra-Posada ${ }^{1}$, Joseph Cutler ${ }^{2}$
}

${ }^{1}$ Agronomist, PhD., Faculty of Agricultural Sciences, Research Group in Plant Ecophysiology. Pedagogical and Technological University of Colombia (UPTC), Tunja - Boyacá, Colombia; corresponding author: fanor.casierra@uptc.edu.co; ${ }^{2}$ Agronomist, MSc. Humboldt Universtät zu Berlin, Berlin, Germany, e-mail: joseph.cutler@agrar.hu-berlin.de

Rev. U.D.C.A Act. \& Div. Cient. 20(2): 321-328, Julio Diciembre, 2017

\section{SUMMARY}

Waterlogging stress is a limiting factor in the production of crops grown in localities with high rainfall frequency. Waterlogging causes a decrease in the availability of $\mathrm{O}_{2}$ in roots, which substantially affects the anatomy, morphology and metabolism of plants. Oxygen deficiency inhibits mitochondrial respiration, oxidation, and oxygenation processes, causing severe affection of plant metabolism. A test in greenhouse conditions was carried out in Tunja, Colombia, in order to evaluate the effect of waterlogging on the growth of cabbage plants (Brassica oleracea var. capitata). Some plants were waterlogged for 25 days and their physiological response was compared with plants maintained at field capacity. As consequence of waterlogging, leaf area, total dry weight, chlorophyll content, leaf area ratio, absolute growth rate and relative growth rate were reduced. In addition, necrotic plants exhibited a high percentage of necrosis in the leaves. As for the variables related to chlorophyll fluorescence, there was a decrease of 17,9, 50,0 and $36,0 \%$ in the $F_{v} / F_{m}$ values, $\Phi$ PSII and $q P$, respectively. All of these results indicate low tolerance of cabbage plants to waterlogging.

Key words: Biomass, chlorophyll content, relative growth rate, $\Phi \mathrm{PSII}, F_{v} / F_{m}$.

\section{RESUMEN}

El estrés por encharcamiento es un factor limitante en la producción de algunos cultivos que se desarrollan en localidades, con alta frecuencia de lluvias. El encharcamiento causa disminución en la disponibilidad de $\mathrm{O}_{2}$ en las raíces, lo cual, afecta sustancialmente la anatomía, la morfología y el metabolismo de las plantas. El déficit de oxígeno inhibe la respiración mitocondrial, la oxidación y los procesos de oxigenación, con lo cual, el metabolismo de la planta resulta severamente afectado. Se desarrolló en Tunja, Colombia, un ensayo en condiciones de invernadero, con el propósito de evaluar el efecto del encharcamiento sobre el crecimiento de plantas de repollo (Brassica oleracea var. capitata). Algunas plantas fueron encharcadas durante 25 días y su respuesta fisiológica se comparó con la de plantas mantenidas a capacidad de campo. Como consecuencia del encharcamiento, se redujo el área foliar, el peso seco total, el contenido de clorofila y los valores de la relación de área foliar, de la tasa absoluta de crecimiento y de la tasa relativa de crecimiento. Adicionalmente, solo en las plantas expuestas al encharcamiento, se presentó necrosis en las hojas, en un alto porcentaje. En cuanto a las variables relacionadas con la fluorescencia de la clorofila, se registró una disminución de 17,$9 ; 50,0$ y $36,0 \%$, en los valores de $F_{v} / F_{m}$, $\Phi$ PSII and $q P$, respectivamente. El conjunto de estos resultados indica baja tolerancia de las plantas de repollo al encharcamiento.

Palabras clave: Biomasa, contenido de clorofila, tasa relativa de crecimiento, $\Phi$ PSII, $F_{v} / F_{m}$.

\section{INTRODUCTION}

As consequence of climate change, there have been frequent occurrences of abundant rains that cause waterlogging and flooding in crops. This phenomenon has intensified in Colombia since 2007, causing conditions of hypoxia to the roots, as consequence of poor soil drainage. In this way, climate change has a direct effect on the growth, 
development, production and quality of agricultural products. However, in some cases, the response of plants to these conditions may be favorable, but at other times, the results may be negative, especially when there are extreme changes in the environment (Fischer et al. 2016). Additionally, Wood et al. (2000) report that in Latin America, about $11,3 \%$ of the areas potentially suitable for cultivation have poor drainage, because topography promotes waterlogging, high water levels and the presence of stagnant surface waters.

Roots in waterlogged soils experience rapid oxygen depletion because of respiration both of the roots and the rootassociated microbiome. Roots exposed to waterlogging switch to the inefficient anaerobic fermentation, consuming available carbohydrate reserves for the generation of needed ATP to remain alive and functioning. As the hypoxic or anoxic situation continues, impaired membrane integrity, starvation and diffusion of phytotoxic compounds into the root cells combine to hinder root growth and function (Vwioko et al. 2017).

Loreti et al. (2016) mention that when plant oxygen availability is limited, the reprogramming of gene expression leading to anaerobic respiration and fermentation is induced, which has negative consequences on ATP production. In addition, according to Ashraf (2012), under these conditions, oxidative stress, alterations in nutrient levels, and anatomical and morphological changes occur in plants. Therefore, the effects of waterlogging induce a reduction in dry mass production (Pedó et al. 2015), an increase in total root length and a decrease in leaf area (Casierra-Posada \& Gómez, 2008), alterations in dry matter partitioning in the different organs (Casierra-Posada \& Vargas, 2007), leaf necrosis (Oliveira et al. 2015) and reduction in the rate of photosynthesis, stomatal conductance and chlorophyll content have also been observed (Kozlowski, 1997).

The analysis of the fluorescence emission of photosynthetic chlorophyll a from photosystem II (PSII) of the plants makes it possible to characterize the effects and modes of action of different types of biotic and abiotic stress (Baker, 2008). Ashraf (2012) mentions that the use of chlorophyll fluorescence as an indicator of waterlogging stress is due to the fact that chlorophyll fluorescence is a physiological factor that determines the primary processes related to photosynthesis, such as, transfer of excitation energy, light absorption and photochemical reactions taking place in the PSII. In this sense, Mielke \& Schaffer (2010) evaluated the intensity of light combined with the exposure time of Eugenia uniflora plants to flooding and found differences for the interaction of the two variables regarding the value of maximum quantum efficiency of PSII Photochemistry $\left(F_{v} /\right.$ $F_{m}$ ), which decreased with the time of exposure to flooding.
Plants exposed to waterlogged conditions are affected by gas exchange limitations, nutrient deficiencies and toxicities. The shoot system of plants exhibit wilting, premature yellowing of leaves, epinasty, stem deformation, shoot length and leaf area reduction, among other problems (Ashraf, 2012). In this work, we attempted to study the mechanisms of tolerance of cabbage plants to waterlogging emphasizing the morphological and metabolic adaptive mechanisms under oxygen deficient environments, because waterlogging is a recurring event in tropical countries, to which horticultural crops are especially sensitive. In this regard, Fischer et al. (2016) mention waterlogging and flooding as stressors, which have intensified due to climate change. Based on these arguments, the objective of the present work was to determine the effect of waterlogging on the fluorescence of chlorophyll and growth in cabbage plants (Brassica oleracea var. capitata).

\section{MATERIALS \& METHODS}

The study was carried out under greenhouse conditions, at the Universidad Pedagógica y Tecnológica de Colombia, located at an altitude of 2.789 m.a.s.l. During the period of development of the test, the average temperature was $15.8^{\circ} \mathrm{C}$, with a relative humidity of $72 \%$ and illumination of $606,04 \pm 362,9 \mu \mathrm{mol} \mathrm{m}^{-2} \mathrm{~s}^{-1}$ inside the greenhouse.

Cabbage seedlings (Brassica oleracea var. capitata L.), Delus hybrid (Seminis - Monsanto, Creve Coeur, Missouri, USA) were used. Transplanting was performed when the plants had 2-3 leaves, placing them in pots with a capacity of $4 \mathrm{~kg}$ of soil. For the control treatment, 28 plants were taken, which were maintained at field capacity. Another 28 plants were submitted to waterlogging 21 days after the transplanting. Plants were kept in the greenhouse until they presented symptoms of flood stress and were harvested 46 days after transplanting when symptoms of flood stress were more clearly manifested, so that plants exposed to waterlogging had undergone this condition during 25 days.

The total leaf area was determined using a Li-Color 3000A analyzer (Li-Cor, Lincoln, Nebraska, USA). Necrotic leaf area was calculated based on the percentage of total leaf area affected. For the dry weight variable of the plant, the weight was recorded after the plants were dried in an oven at $75^{\circ} \mathrm{C}$ until the constant dry weight was reached. The leaf area ratio (LAR), the absolute growth rate (AGR) and the relative growth rate (RGR) were calculated based on the methodology proposed by Hunt (1990). The chlorophyll content index (CCI) was determined when plants exhibited stress symptoms using a CCM 200 Plus meter (Opti-Sciences, Hudson, USA). For the determination of the maximum photochemical quantum yield of photosystem II $\left(F_{v} / F_{m}\right)$, effective quantum yield of photosystem II (ФPSII), and coefficient of photochemical 
fluorescence quenching $(q P)$, two leaves of the middle third of each plant were selected and adapted to dark conditions. Leaf temperature at the time of fluorescence measurement was $20.7 \pm 1.3^{\circ} \mathrm{C}$. An actinic light pulse of $820 \mu \mathrm{mol} \mathrm{m}^{-2} \mathrm{~s}^{-}$ ${ }^{1}$ was used. The measurements were performed very low illumination, using a Mini-Pam-II photosynthesis yield analyzer (Heinz Walz GmbH, Germany).

The experiment consisted of a completely randomized design, of which factors were the control treatment (soil on field capacity) and the soil flooding. This experimental arrangement consisted of twenty-eight replicates by treatment, taking one plant as a replication. An analysis of variance was performed with the Tukey's honest significance test $(P \leq 0.01)$, by means of the SPSS (IBM ${ }^{\circledR}$ SPSS ${ }^{\circledR}$ Statistics) version 20.0.

\section{RESULTS AND DISCUSSION}

Growth related variables: From the collected information, it was possible to determine that the flooding induced a $69.7 \%$ reduction of the total dry weight of the plants, when compared to the control plants, with a highly significant statistical difference (Table 1). It has been reported that the low availability of oxygen in the substrate induced by waterlogging conditions and the low soil redox potential, negatively and significantly affect several aspects of plant physiology. Changes in carbon assimilation and nutrients uptake can be mentioned among these aspects. In addition, root metabolism is significantly impaired (Kozlowski, 1997; Pezeshki, 2001; Kreuzwieser et al. 2004).
Kozlowski (1997) and Casierra-Posada \& Vargas (2007) mention that flooding and waterlogging cause alterations in vegetative and reproductive growth and changes in plant anatomy, and induce early organs senescence and mortality in plants. However, the responses of plants grown under this environmental condition are highly dependent on the genotype, plant age, waterlogging conditions and the time that plants remain flooded. In addition, waterlogging causes reduction in the photosynthetic rate in many angiosperms and gynmosperms, which is reduced within a few hours after the plants have been flooded. In addition, Ahmed et al. (2002) reported the closure of stomata as a consequence of this stress-causing factor, caused by a reduction in hydraulic conductivity of the roots, which normally leads water stress. However, this is not a general condition for all plants, since in some cases the stomata are closed, but the leaves remain turgid even when the plants have remained more than 20 days underwater. On the other hand, Ashraf (2012) mentions that in plants of Pisum sativum, the closing of the stomata is attributed to the transport of abscisic acid from the old leaves to the young ones, and also to the de novo synthesis of this hormone in plants under water.

Casierra-Posada \& Gómez (2008) reported that under waterlogging conditions, two species of Furcraea reduced biomass production from 38,9 to $48,0 \%$ in relation to the control, whereas in different cultivars of Fragaria sp, biomass was reduced between 45,9 and $52,9 \%$ in waterlogged plants, compared to control plants (Casierra-Posada \& Vargas, 2007; Fischer et al. 2016). These authors justify these findings based on anaerobic respiration in the roots, as a

Table 1. Variables used to determine the effect of waterlogging on cabbage plants (Brassica oleracea var. capitata).

\begin{tabular}{|l|c|c|c|}
\hline \multicolumn{1}{|c|}{ Source of Variation } & Non-waterlogged & waterlogged & Significance \\
\hline Total dry weight $(\mathrm{g})$ & $2.35 \pm 0.54 \mathrm{a}$ & $0.71 \pm 0.27 \mathrm{~b}$ & $* *$ \\
\hline Leaf area $\left(\mathrm{cm}^{2}\right)$ & $157.12 \pm 56.40 \mathrm{a}$ & $30.25 \pm 12.89 \mathrm{~b}$ & $* *$ \\
\hline Necrosed leaf area $(\%)$ & $0.0 \pm 0.0 \mathrm{~b}$ & $31.02 \pm 14.58 \mathrm{a}$ & $* *$ \\
\hline Chlorophyll Content Index & $42.81 \pm 8.27 \mathrm{a}$ & $36.48 \pm 10.92 \mathrm{~b}$ & $*$ \\
\hline Leaf area ratio $\left(\mathrm{m}^{2} \mathrm{~g}^{-1}\right)$ & $6.9 * 10^{-3} \pm 0.002 \mathrm{a}$ & $4.4 * 10^{-3} \pm 0.0012 \mathrm{~b}$ & $* *$ \\
\hline Absolute growth rate $\left(\mathrm{g} \mathrm{d}^{-1}\right)$ & $0.038 \pm 0.01 \mathrm{a}$ & $0.0036 \pm 0.005 \mathrm{~b}$ & $* *$ \\
\hline Relative growth rate $\left(\mathrm{g} \mathrm{g}^{-1} \mathrm{~d}^{-1}\right)$ & $0.0124 \pm 0.003 \mathrm{a}$ & $0.0019 \pm 0.002 \mathrm{~b}$ & $* *$ \\
\hline$F_{v} / F_{m}$ & $0.78 \pm 0.06 \mathrm{a}$ & $0.64 \pm 0.166 \mathrm{~b}$ & $* *$ \\
\hline$\Phi P S I I$ & $0.6 \pm 0.03 \mathrm{a}$ & $0.3 \pm 0.04 \mathrm{~b}$ & $* *$ \\
\hline$q P$ & $0.11 \pm 0.06 \mathrm{a}$ & $0.07 \pm 0,07 \mathrm{~b}$ & $* *$ \\
\hline
\end{tabular}

* Significant at $5 \%$

** Significant at $1 \%$.

Average values in the row, followed by different letter, imply a statistically significant difference according to

the Tukey's honest significance test $(\mathrm{P} \leq 0.01)$.

The average values in each case are followed by the value of the standard deviation. 
consequence of hypoxia in the substrate, and in the reduction of the photosynthetic rate, frequently reported in flooded plants, where the stomata closure also occurs, which has as consequence a decrease of the $\mathrm{CO}_{2}$ exchange rate and therefore, the carboxylation reduces. This response may not be immediate and initially the net photosynthesis rate can be maintained with few variations, due to the sub-stomatal $\mathrm{CO}_{2}$ concentration.

Additionally, it is reported that at low availability of oxygen in the substrate, reactive oxygen species (ROS) are produced, which alter a large number of processes in plants. These ROS include superoxide $\left(\mathrm{O}_{2}{ }^{-}\right)$, hydrogen peroxide $\left(\mathrm{H}_{2} \mathrm{O}_{2}\right)$ and the hydroxyl radical $\left({ }^{\circ} \mathrm{OH}\right)$. In this regard, high $\mathrm{H}_{2} \mathrm{O}_{2}$ contents can lead to the inhibition of the Calvin cycle (Ashraf, 2012), with negative consequences for the carbon fixation during photosynthesis, which decreases total dry matter.

In relation to the control plants, the leaf area of the waterlogged plants was reduced by $80,2 \%$. Furthermore, it was found that the plants submitted to water excess conditions had a $31,0 \%$ necrotic leaf area, whereas in the control plants this symptomatology was not present. A statistical difference was found in this respect (Table 1). The decrease of leaf area and presence of leaf necrosis has been reported to be a consequence of waterlogging. Leaf necrosis appears in plants exposed to flooding when plants are exposed to this type of abiotic stress (Oliveira et al. 2015; Casierra-Posada \& Vargas, 2007). Casierra-Posada \& Vargas (2007) found that in different cultivars of Fragaria, waterlogging induced leaf necrosis of $30,1-41,2 \%$, while no necrosis occurred in the control plants. Similarly, Oliveira et al. (2015) report necrosis on leaves of Aspidosperma macrocarpon and Kielmeyera coriacea seedlings exposed to waterlogging. On the other hand, Casierra-Posada \& Gómez (2008) found that in Furcraea macrophylla the flooding reduced $41,5 \%$ of the leaf area, while in Furcraea castilla, 32,7\%. Additionally, Oliveira et al. (2015) reported that in seedlings of six forest species, the soaked plants had a leaf area of $90,0 \mathrm{dm}^{2}$, while in the control plants, a leaf area of $125,9 \mathrm{dm}^{2}$ was found.

Excess water in the soil causes inhibition of the Krebs cycle and alterations in the respiratory chain, since in the roots of plants exposed to this condition anaerobic respiration occurs, resulting in a lower production of ATP, which can affect several metabolic processes in plants (Casierra-Posada \& Gómez, 2008). In addition, increased leaf chlorosis and senescence are common symptoms in plants that are not tolerant to waterlogging (Pezeshki, 1994). All these approaches suggest that flooding has a strong impact on leaf growth and leaf area development.

Compared to control plants, leaf area ratio (LAR) was reduced by $36,2 \%$ in soaked plants. The higher values of LAR found in the control plants are proof that most of the produced assimilates during the photosynthetic process are destined to the formation of leaves. This occurs in order to obtain a greater absorption of the incident radiation. On the contrary, the reduction in the value of the LAR presented in the plants submitted to waterlogging indicates the reduction in the leaf area available for photosynthesis (Pedó et al. 2015). These authors explain that the observed decrease in LAR values in Secale cereale plants may express the gradual increase of non-assimilated tissues, as well as the formation of reproductive structures, which present a high sink strength.

The waterlogging reduced the absolute growth rate (AGR) and relative growth rate (RGR), 90,5 and $84,6 \%$, respectively, when compared to the control plants. In relation to these two variants of growth rates, Hunt (1990) mentiones that while AGR is the simplest index to express plant growth, RGR facilitates more equitable comparisons than when AGR is used. Therefore, Poorter et al. (2012) use RGR instead of AGR to express growth in plants. They mention that since the value of the LAR indicates the amount of leaf area that is in the dry mass of a plant, this is the factor that has a strong influence on the photosynthetic rate and respiration, from which the RGR results. In agreement with this approach, a direct relation between the values of the LAR and RGR was found in our study. The values of these two variables decreased with waterlogging. The decrease in the value of the LAR caused a decrease in the photosynthetic rate reflected in the RGR value and also in the value of the dry mass found in soaked plants, in relation to the plants maintained at field capacity.

Chlorophyll content: Chlorophyll content index (CCI) was reduced by $14,7 \%$, in comparison to the control plants, with a statistically significant difference $(P \leq 0.05)$. In this regard, Ezin et al. (2010) mention that both chlorophyll fluorescence and SPAD (Special Products Analysis Division) records would be good indicators when selecting cultivars of Lycopersicon esculentum with respect to their tolerance to flooding. Additionally, Baruah, (1996) and Sarkar et al. (1996) reported that in Oryza sativa, the ability to conserve chlorophyll content in plants exposed to flooding is considered a mechanism of tolerance to this stress-causing factor. In this study, the reduction in chlorophyll content presented a low statistical difference at $5 \%$ level, whereas for all other variables evaluated, a statistically significant difference was found at $1 \%$. This can be justified by the fact that the flooding not only reduced the leaf area but also induced necrosis in the leaves, so that the plants had to develop a compensation mechanism such as the additional production of chlorophyll, in order to guarantee their survival. This aspect can be corroborated by the reduction of the value of the LAR in soaked plants, which indicates a decrease of the leaf area available for photosynthesis, according to Pedó et al. (2015). 
Grzesiak et al. (2017) indicated that soil compaction, drought and waterlogging stresses cause alterations on dry matter accumulation in roots and shoots, shoot to root ratio, membrane injury, chlorophyll content (SPAD), leaf and root water potential, gas exchange parameters and water use efficiency. These stressors are multidimensional environmental factors that have considerable effects on plant growth, development and yield. Therefore, the impact of combined stresses on the physiology of crop plants is key to understanding stress susceptibility mechanisms under natural field conditions.

Although stomatal closure is a commonly reported consequence in plants growing exposed to waterlogging, the reduction induced by this factor in terms of carbon assimilation can also be attributed to limitations in the rate of photosynthesis that do not involve the stomata (Herrera et al. 2008). These alterations in carbon assimilation may have their origin in changes in the content of photosynthetic pigments and in alterations in the content of enzymes involved in carboxylation (Kozlowski 1997; Pezeshki 2001). However, in the present work, in addition to the causes argued to justify the reduction in the assimilation of carbon in waterlogged plants, reflected in the reduction of biomass, one must take into account the drastic reduction in the leaf area registered in plants subjected to this stressor, which substantially decreases the photosynthetic area.

As in the present work, Mielke \& Schaffer (2010) reported a reduction in the average value of the $\mathrm{CCI}$ in seedlings of Eugenia uniflora that grew under flooding. The value of the $\mathrm{CCI}$ in the control plants was $2,0 \%$ above the value registered in soaked plants, with statistical differences only at $5 \%$. Also Ezin et al. (2010) found significant differences in SPAD values in only one of the four Lycopersicon esculentum evaluated genotypes in relation to ponding. In this genotypes, flooding reduced the value of SPAD records compared to control plants. In addition, Tiryakioğlu et al. (2015) found a decrease in the contents of chlorophyll $a$, chlorophyll $b$ and carotenoids in seedlings of Triticum aestivum subjected to flooding.

Chlorophyll fluorescence: It was found that flooding induced a reduction of $17,9 \%$ in the value recorded for the maximum photochemical quantum yield of photosystem II $\left(F_{v} / F_{m}\right)$, in relation to the value found in the control plants. In this regard, Baker (2008) mentions that in many ecophysiological studies it is suggested that the decreases found in the value of $F_{v} / F_{m}$ as a consequence of the exposure of the plants to some stressor, imply that the photosynthetic efficiency of the leaves in light conditions was affected. In this sense, the $F_{v} / F_{m}$ coefficient has been widely used as an indicator of photoinhibition of photosynthesis (Maxwell \& Johnson, 2000; Casierra-Posada, 2007; Baker, 2008). Moreover, according to Mohammed et al. (2003), the value of this variable in healthy plants should be in the range of 0,83-0,76, which was the value of the $F_{v} / F_{m}$ measured in the control plants in the present work. Thus, according to Ashraf (2012), it can be said that the reduction in the value of $F_{v} / F_{m}$ is an indicator of the sensitivity of the photosynthetic apparatus to the abiotic stressors, and of the plants' inability to regenerate the Rubisco when they are exposed to stress conditions. In spite of the previously mentioned approaches, Baker (2008) indicate that it should be taken into account that the value of $F_{v} / F_{m}$ recorded in leaves previously adapted to darkness is a useful relative measure of the maximum quantum yield of photochemistry of the photosystem II (PSII), but does not provide an accurate quantitative value of the quantum yield. In the present work, the flooding did not induce a very high difference in the value of $F_{v} / F_{m}$ recorded in leaves previously adapted to the darkness, since in the plants exposed to flooding a value of 0.64 was recorded, which, according to Mohammed et al. (2003), would be a value in the category of "fair" (0.69-0.66). The difference of the value of $F_{v} / F_{m}$ in the two treatments in the present investigation does not suggest that the soaked plants were under a severe strain. Waterlogging negatively influenced the values of the growth-related variables recorded in the plants and the dry weight. This also has a severe effect on the factors involved in photosynthesis, which can be explained based on the approach of Živčák et al. (2014), who mention that the value of $F_{v} / F_{m}$, in some cases, is not sensitive enough to determine the effect some stressors have on the decline of photosynthesis.

The effective quantum yield of photosystem II (ФPSII) was reduced by $50 \%$ in the waterlogged plants, compared to the control plants. Determination of $\Phi P S I I$ has an advantage, since this variable is more sensitive to a large number of stressors than the $F_{v} / F_{m}$ value, according to Fernandes et al. (2012) since it has been found that the reduced plant health under prolonged soaking may result in biochemical alterations such as restriction of ribulose bisphosphate carboxylase (RuBPC), phosphoglycollate and glycollate oxidase activity, as well as severe damage to chloroplast membranes. These alterations restrict the electron transport chain during photosynthesis and negatively alter the efficiency of PSII (Ashraf, 2012). In this respect, the recorded values for ФPSII in the present test were found to be more in agreement with the reduction of dry matter recorded in plants submitted to waterlogging, and in general, with all variables related to plant growth. These results agree with the results reported by Ren et al. (2016) who also found a decrease in the value of the effective quantum yield of photosystem II (ФPSII) in Zea mays plants subjected to flooding. Their studies indicate that flooding induces damage to PSII, the potential energy for photosynthesis is reduced, leading to a decrease in the photosynthetic rate and therefore to a reduction in the grain yield. 
Similar to the results found in this work, Tubuxin et al. (2015) found a high correlation between the content of chlorophyll and the effective quantum yield of photosystem II (ФPSII). Therefore, it can be assumed that the decrease of the CCI found in plants submitted to waterlogging in the present study, affected the value of $\Phi P S I I$ in the same way. This effect also led to the reduction of the photosynthetic rate and, consequently, the growth and the production of dry matter in soaked plants.

The value of the coefficient of photochemical fluorescence quenching $(q P)$ was reduced by $36 \%$ in the waterlogged plants compared to plants maintained at field capacity (control). According to Baker (2008), the $q P$ value has been frequently used to estimate the redox state of the $Q_{A}$ (the primary quinone electron acceptor of PSII). However, in many cases, there is no linear relationship between $q P$ and the number of PSII centers that are open, so changes recorded in the value of $q P$ should not always be used to estimate the redox state of QA. In this study plants subjected to waterlogging, had a $q P$ value that reduced considerably, indicating that the plants were under stress, since Mohammed et al. (2003) indicate that in healthy plants, the value of $q P$ is between $0,8-1,0$. Mohammed et al. (2003) mention that in plants subjected to some type of stress, the final value of $q P$ is reduced considerably, compared to control plants. The findings of this study are in agreement with the results reported by Wu et al. (2015) who report a reduction in the value of qP Triticum aestivum plants exposed to flooding. These authors mention that the reduction found in the soaked plants was mainly due to the reduction in the efficiency of excitation energy capture of the open PSII reaction centers.

Waterlogging Tolerance: Loreti et al. (2016) point out that waterlogging tolerance implies a balance between the factors involved in anaerobic root respiration and other mechanisms that can prevent carbon starvation and oxidative stress. On the other hand, Zou et al. (2015) suggest that abscisic acid (ABA) plays a key role in the development of tolerance of Brassica napus plants to flooding stress. According to Parent et al. (2008), in general, the tolerance of plants to waterlogging can be evaluated based on the growth, development and survival of plants; the production of some proteins during hypoxic conditions; the reduction in stomatal conductance, photosynthesis and root hydraulic conductivity; the efficient use of carbohydrates; the formation of hypertrophied lenticels, development of aerenchyma and adventitious roots.

Conclusions and perspectives: Based on the studied approaches, plants of Brassica oleracea var. capitata would have little tolerance to this stress-causing factor, since the variables related to growth, chlorophyll content and variables related to plant fluorescence were severely affected by the exposure of plants to waterlogging. In conclusion, the planting of this vegetable in potentially rainy seasons is not suggested. Study of regulatory mechanisms and signaling events responsible for triggering responses to oxygen depletion conditions in plants is a fascinating research field. Understanding the signaling mechanisms that determine the organ and whole plant response to oxygen deprivation, regulation of leaf and internode elongation, petiole curvature, aerenchyma formation and adventitious root growth is another attractive area for research. The study of these approaches will be of relevance to horticulture and will provide knowledge of the fundamental nature of the behavior of plants exposed to flooding and waterlogging.

Acknowledgments: The authors are grateful for the collaboration of the engineer Alexander Carrreño Patiño, for his data contribution. Conflict of interests: The manuscript was prepared and reviewed with the participation of the authors, who declare that there exists no conflict of interest that puts in risk the validity of the results presented.

\section{BIBLIOGRAPHY}

1. AHMED, S.; NAWATA, E.; HOSOKAWA, M.; DOMAE, Y.; SAKURATANI, T. 2002. Alterations in photosynthesis and some antioxidant enzymatic activities of mungbean subjected to waterlogging. Plant Sci. 163(1):117-123.

2. ASHRAF, M. 2012. Waterlogging stress in plants: A review. Afr. J. Agr. Res. 7(13):1976-1981.

3. BAKER, N.R. 2008. Chlorophyll fluorescence: a probe of photosynthesis in vivo. Ann. Rev. Plant Biol. 59:89113.

4. BARUAH, K.K. 1996. Physiological disorder in rice (Oryza sativa L.). I. Effect of flooding. Indian J. Agr. Res. 30:101-108.

5. CASIERRA-POSADA, F. 2007. Fotoinhibición: Respuesta fisiológica de los vegetales al estrés por exceso de luz. Una revisión. Rev. Col. Ciencias Hortícolas. 1(1):114-123.

6. CASIERRA-POSADA, F.; VARGAS, Y.A. 2007. Crecimiento y producción de fruta en cultivares de fresa (Fragaria sp.) afectados por encharcamiento. Rev. Col. Ciencias Hortícolas 1(1):21-32.

7. CASIERRA-POSADA, F.; GÓMEZ, N.E. 2008. Crecimiento foliar y radical en plantas de fique (Furcraea castilla 
y F. macrophylla) bajo estrés por encharcamiento. Agronomía Colombiana. 26(3):381-388.

8. EZIN, V.; De La PENA, R.; AHANCHEDE, A. 2010. Flooding tolerance of tomato genotypes during vegetative and reproductive stages. Brazilian J. Plant Physiology 22(2):131-142.

9. FERNANDES, D.R.P.; CAETANO, V.S.; TENÓRIO, M.M.B.; REINERT, F.; YONESHIGUE-VALENTIN, Y. 2012. Characterization of the photosynthetic conditions and pigment profiles of the colour strains of Hypnea musciformis from field-collected and in vitro cultured samples. Rev. Brasileira de Farmacognosia. 22(4):753-759.

10. FISCHER, G.; RAMÍREZ, F.; CASIERRA-POSADA, F. 2016. Ecophysiological aspects of fruit crops in the era of climate change. A review. Agronomía Colombiana. 34(2):190-199.

11. GRZESIAK, M.T.; HURA, K.; JURCZYK, B.; HURA, T.; RUT, G.; SZCZYREK, P.; GRZESIAK, S. 2017. Physiological markers of stress susceptibility in maize and triticale under different soil compactions and/or soil water contents. J. Plant Interact. 12(1):355-372.

12. HERRERA, A.; TEZARA, W.; MARÍN, O.; RENGIFO, E. 2008. Stomatal and non-stomatal limitations of photosynthesis in trees of a tropical seasonally flooded forest. Physiol. Plant 134:41-48.

13. HUNT, R. 1990. Basic growth analysis: Plant growth analysis for beginners. London; Boston. Unwin Hyman. 112p.

14. KOZLOWSKI, T.T. 1997. Responses of woody plants to flooding and salinity. Tree Physiol. Monogr. 1:1-29.

15. KREUZWIESER, J.; PAPADOPOULOU, E.; RENNENBERG, H. 2004. Interaction of flooding with carbon metabolism of forest trees. Plant Biol. 6:299306.

16. LORETI, E.; van VEEN, H.; PERATA, P. 2016. Plant responses to flooding stress. Curr Opin Plant Biol 33:64-71. Doi: 10.1016/j.pbi.2016.06.005.

17. MAXWELL, K.; JOHNSON, G.N. 2000. Chlorophyll fluorescence: a practical guide. J Exp Bot 51:659668.

18. MIELKE, M.S.; SCHAFFER, B. 2010. Leaf gas exchange, chlorophyll fluorescence and pigment indexes of
Eugenia uniflora L. in response to changes in light intensity and soil flooding. Tree Physiol 30(1):45-55.

19. MOHAMMED, G.H.; ZARCO-TEJADA, P.; MILLER, J.R. 2003. Applications of Chlorophyll Fluorescence in Forestry and Ecophysiology. In: DeEll, J.R.; Toivonen, P.M.A. (eds), Practical applications of chlorophyll fluorescence in plant biology. Kluwer Academic Publishers. Norwell, USA. p.79-124.

20. OLIVEIRA, A.S.D.; FERREIRA, C.S.; GRACIANORIBEIRO, D.; FRANCO, A.C. 2015. Anatomical and morphological modifications in response to flooding by six Cerrado tree species. Acta Bot, Bras, 29(4):478-488.

21. PARENT, C.; CAPELLI, N.; BERGER, A.; CRÈVECOEUR, M.; DAT, J.F. 2008. An overview of plant responses to soil waterlogging. Plant Stress 2(1):20-27

22. PEDÓ, T.; MARTINAZZO, E.G.; AUMONDE, T.Z.; VILLELA, F.A. 2015. Plant growth analysis and seed vigor expression: effects of soil waterlogging during rye plant development. Acta Bot. Bras. 29(1):01-07.

23. PEZESHKI, S.R. 1994. Plant response to flooding. In: WILKINSON, R.E. (Ed.). Plant-environment interactions. New York. M. Dekker. p.289-321.

24. PEZESHKI, S.R. 2001. Wetland plant responses to soil flooding. Env. Exp. Bot. 46:299-312.

25. POORTER, H.; NIKLAS, K.J.; REICH, P.B.; OLEKSYN, J.; POOT, P.; MOMMER, L. 2012. Biomass allocation to leaves, stems and roots: Meta-analyses of interspecific variation and environmental control. New Phytologist 193:1-21.

26. REN, B.; ZHANG, J.; DONG S.; LIU; P.; ZHAO, B. 2016. Effects of waterlogging on leaf mesophyll cell ultrastructure and photosynthetic characteristics of summer maize. PLoS ONE 11(9):e0161424.

27. SARKAR, R.K.; DE, R.N.; REDDY, J.N.; RAMAKRISHNAYYA, G. 1996. Studies on the submergence tolerance mechanism in relation to carbohydrate, chlorophyll and specific leaf weight in rice (Oryza sativa L.). J. Plant Physiol. 149:623-625.

28. TIRYAKIOĞLU, M.; KARANLIK, S.; ARSLAN, M. 2015. Response of bread-wheat seedlings to waterlogging stress. Turk. J. Agric. For. 39:807-816. 
29. TUBUXIN, B.; RAHIMZADEH-BAJGIRAN, P.; GINNAN, Y.; HOSOI, F.; OMASA, K. 2015. Estimating chlorophyll content and photochemical yield of photosystem II (ФPSII) using solar-induced chlorophyll fluorescence measurements at different growing stages of attached leaves. J. Exp. Bot. 66(18):5595-603.

30. VWIOKO, E.; ADINKWU, O.; EL-ESAWI, M.A. 2017. Comparative physiological, biochemical, and genetic responses to prolonged waterlogging stress in okra and maize given exogenous ethylene priming. Front. Physiol. 8:632. doi.org/10.3389/fphys.2017.00632

31. WOOD, S.; SEBASTIAN, K.; SCHERR, S. 2000. Soil resource condition. In: Pilot analysis of global ecosystems: Agroecosystems. International Food Policy Research Institute and the World Resources Institute, Washington, D.C. p.45-54.

32. WU, X.; TANG, Y.; LI, C.; WU, C.; HUANG, G. 2015. Chlorophyll fluorescence and yield responses of winter wheat to waterlogging at different growth stages. Plant Prod. Sci. 18(3):284-294.

33. ŽIVČÁK, M.; OLŠOVSKÁ, K.; SLAMKA, P.; GALAMBOŠOVÁ, J.; RATAJ, V.; SHAO, H.B.; KALAJI, H.M.; BRESTIČ, M. 2014. Measurements of chlorophyll fluorescence in different leaf positions may detect nitrogen deficiency in wheat. ZemdirbysteAgriculture 101:437-444.

34. ZOU, X.L.; ZENG, L.; LU, G.Y.; CHENG, Y.; XU, J.S.; ZHANG, X.K. 2015. Comparison of transcriptomes undergoing waterlogging at the seedling stage between tolerant and sensitive varieties of Brassica napus L. J. Integr. Agr. 14(9):1723-1734.

Recibido: Mayo 19 de 2017

Aceptado: Octubre 16 de 2017

Cómo citar:

Casierra-Posada, F.; Cutler, J. 2017. Photosystem II fluorescence and growth in cabbage plants (Brassica oleracea var. capitata) grown under waterlogging stress. Rev. U.D.C.A Act. \& Div. Cient. 20(2): 321-328. 